\title{
Establishment of an analysis model based on measurement of hepatitis B viral infection serum markers
}

\author{
Yang Guang, Li Yuzhong and Liu Hui* (D)
}

\begin{abstract}
Background: Using serum markers of hepatitis B virus (HBV) infection, we aimed to develop a quantitative model that explains the complicated immune response to this infection.

Methods: Serum samples from HBV-infected patients were randomly selected and divided into groups based on HBV-DNA positivity or negativity. Quantitative markers of HBV were measured. Formulae for Antibody index (IAb) $\left[(\text { anti-HBs * } 1 / \text { anti-HBe }+ \text { anti-HBs * 1/anti-HBC }+1 / \text { anti-HBC * } 1 / \text { anti-HBe })^{0.5}\right]$ and Antigen index $(\mathrm{IAg})[(\mathrm{HBsAg}$ * $\mathrm{HBeAg})^{0.5}$ ] were introduced.

Results: IAg values were statistically higher $(p<0.05)$ in the HBV-DNA-positive group than in the -negative group, but no statistically significant difference in IAb values was observed. When IAb values were $>50$, IAg values were mostly < 250; when IAg values were $>250$, IAb values were mostly $<50$.

Conclusion: IAb and IAg values can efficiently reflect the status of immune response to HBV and may be suitable for assessment of the infection process and the possible outcome of infection.
\end{abstract}

Keywords: Hepatitis B, Biomarker, Mathematical model

\section{Background}

Hepatitis B virus (HBV) infection is a major public health issue worldwide [1-3]. The virus causes both chronic and acute infections. The host immune response causes both hepatocellular damage and clearance of viral antigen [4-6]. Serum markers of HBV infection might help with assessment of various issues such as prognosis [7-9].

Standard methods and reliable, commercial kits have been used to detect either HBV antigens or antibodies produced by the host. Such methods may detect hepatitis B surface antigen (HBsAg), antibody to hepatitis B surface antigen (anti-HBs), hepatitis B e antigen (HBeAg), antibody to hepatitis B e antigen (anti-HBe), or antibody to hepatitis B core antigen (anti-HBc); however, interpretation of these assays is complex [10-12]. The immune response to HBV is initiated after the virus enters the body and shows a complex relationship

\footnotetext{
* Correspondence: liuhui60@sina.com

College of Medical Laboratory, Dalian Medical University, Dalian 116044,
} China

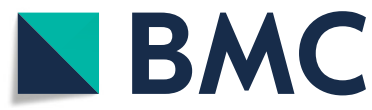

(C) The Author(s). 2019 Open Access This article is distributed under the terms of the Creative Commons Attribution 4.0 International License (http://creativecommons.org/licenses/by/4.0/), which permits unrestricted use, distribution, and reproduction in any medium, provided you give appropriate credit to the original author(s) and the source, provide a link to the Creative Commons license, and indicate if changes were made. The Creative Commons Public Domain Dedication waiver (http://creativecommons.org/publicdomain/zero/1.0/) applies to the data made available in this article, unless otherwise stated. between the incidence and outcome of HBV, i.e. whether the patient is a disease carrier, or will develop chronic infection [7-9].

In previous assessments of anti-HBs, anti-HBe and anti-HBc responses, the data for each antibody were qualitative and the assessment for each marker was independent. Currently, quantitative serum markers of HBV infection have been used widely; however, the classical assessment rules based on qualitative test results continue to be used with quantitative results in associated analysis and studies. Therefore, we developed a new analytical model based on quantitative measurement of serum markers of HBV infection. The model explains the complicated immune response to this infection; the advantages of quantitative detection could be fully applied.

\section{Methods \\ Data source}

In total, 128 original data were collected from hospital patients with HBV infection (defined as HBsAg, HBeAg, 
anti-HBe or anti-HBc positive; 76 males; mean age of all patients $57.4 \pm 13.6$ years) at the Second Affiliated Hospital of Dalian Medical University, China. These patients were newly diagnosed by their physicians and blood samples were collected before they received antiviral treatment. There is seroconversion from an HBeAg-positive phase to an HBeAg-negative, and anti-HBe-positive phase during the natural course of infection [13]. Of 128 such patients, 23,18 and 87 cases were respectively in $\mathrm{HBeAg}$-positive, $\mathrm{HBeAg}$-negative, and anti-HBe-positive phase.

\section{Laboratory tests}

HBV markers (HBsAg, anti-HBs, $\mathrm{HBeAg}$, anti-HBe, and anti-HBc) were measured using a chemiluminescent microparticle immunoassay (Cobas E601 analyzer; F. Hoffmann-La Roche Ltd., Basel, Switzerland) per the manufacturer's protocols. Anti-HBs levels $\geq 10 \mathrm{mIU} / \mathrm{ml}$ were considered positive. Sample value/cut-off values (S/ $\mathrm{CO}$ ) were used as quantitative indicators for $\mathrm{HBsAg}$, $\mathrm{HBeAg}$, anti-HBe, and anti-HBc. S/CO $\geq 1.0$ was defined as positive for $\mathrm{HBsAg}$ and $\mathrm{HBeAg}$. The levels of anti-HBe and anti-HBc in the assays for these molecules are inversely proportional to $\mathrm{S} / \mathrm{CO}$; thus, $\mathrm{S} / \mathrm{CO}$ ratios $\leq 1.0$ were considered anti-HBe and anti-HBc positive.

A real-time fluorescence quantitative PCR system (Roche LightCycler 480II, Roche Ltd., Basel, Switzerland) and commercial diagnostic kits were used for the quantitation of HBV-DNA. The detection values were set at $500 \mathrm{IU} / \mathrm{mL}$ and serum samples with $>500 \mathrm{IU} / \mathrm{mL}$ were considered positive for HBV-DNA.

\section{Establishment of quantitative model}

HBsAg (a serological marker of HBV infection, both acute and chronic) and HBeAg (found in the blood when virus is present) were designated as representing the infection phase; the quantitative value for the infection phase was defined as the Antigen index (IAg). Anti-HBs, anti-HBe and anti-HBc antibodies (found after an acute infection or in chronic HBV carriers) were designated as representing the immune response phase; the quantitative value of the immune response phase was defined as the Antibody index (IAb).

IAb was taken as an example to explain the establishment of the model. The quantitative levels of anti-HBs, anti-HBc and anti-HBe antibodies were used to establish a three-dimensional co-ordinate system; the area of the triangle they formed was the quantitative value of infection phase (Fig. 1). The area of the triangle was calculated as:

$$
\begin{aligned}
\mathrm{S} & =0.5^{*} \sin 60^{*}\left(\text { anti-HBs }{ }^{*} 1 / \text { anti-HBe }^{-H}\right. \\
& \left.+ \text { anti-HBs }{ }^{*} \text { anti-HBc }+ \text { anti-HBc } 1 / \text { anti-HBe }\right)
\end{aligned}
$$

Note, anti-HBc and anti-HBe were determined by applying the competition method, for which (1/anti-HBe and $1 /$ anti-HBc) should be substituted.

As $0.5 * \sin 60$ was constant, it could be omitted in analysis.

Because the quantitative value (S) is a large number that is impractical to work with, the square root of $S$ can be substituted as demonstrated below.

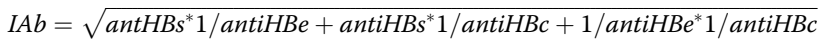

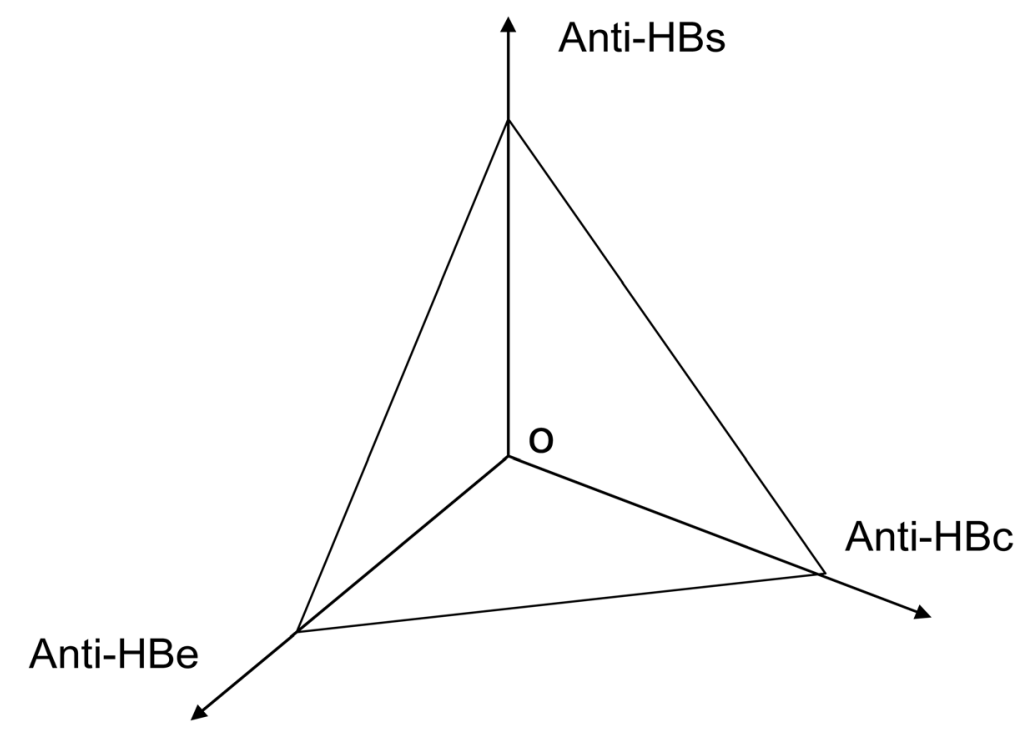

Fig. 1 Schematic diagram of the quantitative analysis model of the immune response to hepatitis B virus (HBV) 
Table 1 Comparison of the HBV marker between two groups of HBV-DNA

\begin{tabular}{|c|c|c|c|c|c|c|c|}
\hline \multirow{2}{*}{$\begin{array}{l}\text { HBV } \\
\text { marker }\end{array}$} & \multicolumn{3}{|c|}{ DNA positive $(n=69)$} & \multicolumn{3}{|c|}{ DNA negative $(n=59)$} & \multirow{2}{*}{$\begin{array}{l}p- \\
\text { value }\end{array}$} \\
\hline & 25th & 50th & 75th & 25th & 50th & 75th & \\
\hline $\mathrm{HBsAg}$ & 1593.750 & 5688.000 & 6942.750 & 0.452 & 0.520 & 346.500 & $<0.001$ \\
\hline Anti-HBs & 1.900 & 1.900 & 9.763 & 1.900 & 16.660 & 127.600 & 0.002 \\
\hline $\mathrm{HBeAg}$ & 0.099 & 0.128 & 234.200 & 0.085 & 0.091 & 0.104 & $<0.001$ \\
\hline Anti-HBe & 0.002 & 0.009 & 1.538 & 0.019 & 0.445 & 1.090 & 0.072 \\
\hline Anti-HBC & 0.007 & 0.009 & 0.010 & 0.007 & 0.007 & 0.008 & $<0.001$ \\
\hline $\mathrm{IAg}$ & 22.695 & 28.413 & 561.247 & 0.194 & 0.218 & 9.151 & $<0.001$ \\
\hline $\mid A b$ & 21.263 & 156.841 & 233.010 & 46.962 & 106.075 & 220.281 & 0.837 \\
\hline
\end{tabular}

Note: Total anti-HBe and anti-HBc activity level was inversely proportional to cut-off value

The calculation theory for IAg was consistent with that for IAb. The formula for IAg is as follow:

$$
\mathrm{IAg}=\sqrt{\mathrm{HBsAg}^{*} \mathrm{HBeAg}}
$$

\section{Statistical analysis}

The IAg and IAb indices were not normally distributed; hence they are stated as quartile values. Difference between groups were analyzed using the Mann-Whitney $U$-test. The relationship between the IAg and IAb indices was assessed using Spearman correlation. Data were considered statistically significant when the probability of a type I error was $\leq 0.05$. Data were analyzed using SPSS ver. 13.0 software for Windows.

\section{Results}

Table 1 shows raw data for the HBV markers IAg and $\mathrm{IAb}$ in the HBV-DNA-positive and -negative groups. IAg values were higher in the HBV-DNA-positive group than in the HBV-DNA-negative group $(p<0.05)$. No significant difference in IAb level was observed between the groups.

Figure 2 shows the distribution of IAg and IAb in patients ( $x$-axis, IAb values; $y$-axis, IAg) as a scatter plot to observe the relationship between IAg and IAb. As shown in Fig. 2, when the values of IAb were greater than 50, the values of IAg were mostly less than 250; when the values of IAg were over 250, the values of IAb were mostly less than 50. Levels of HBV-DNA in groups of scatter plot are shown in Table 2.

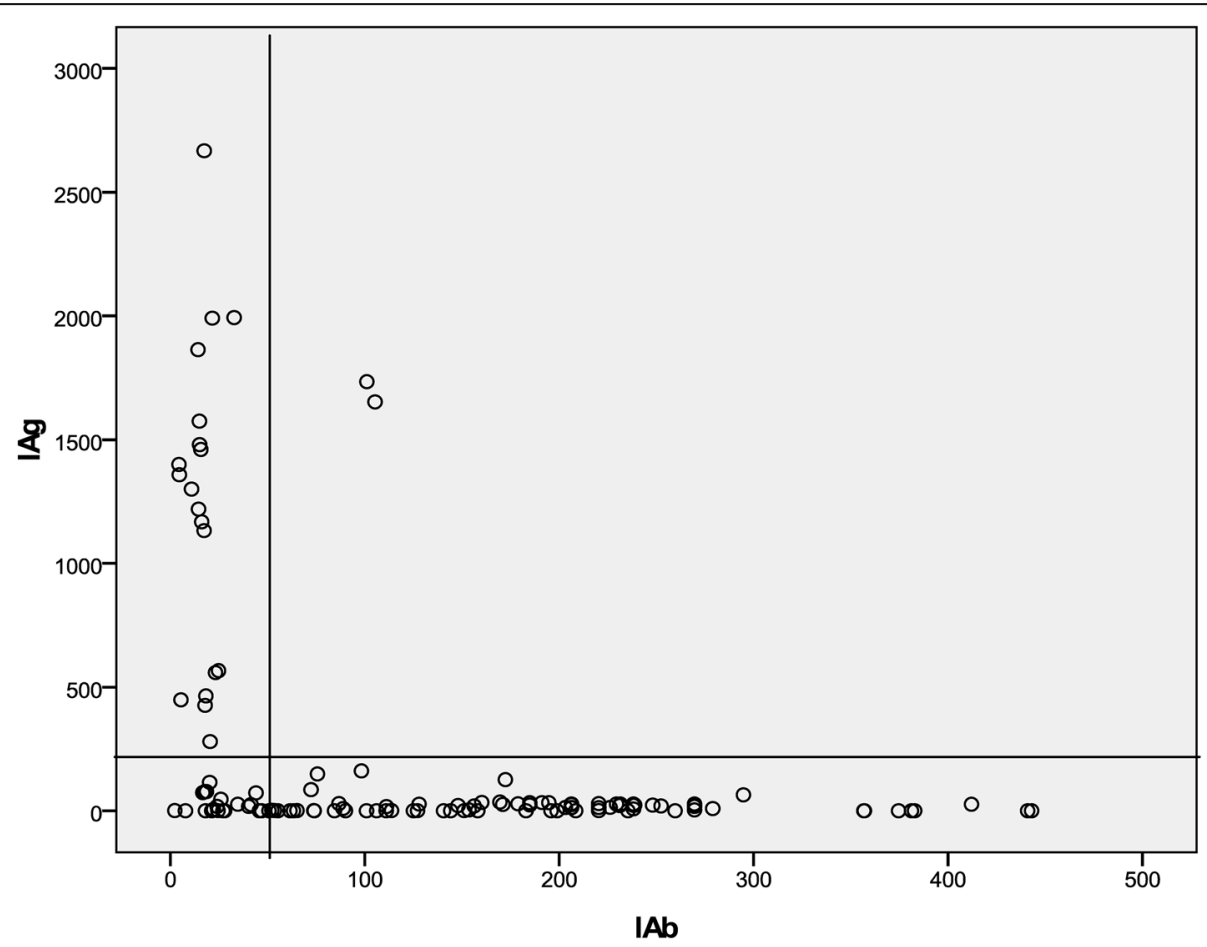

Fig. 2 Relationship between IAg and IAb in 128 patients 
Table 2 Levels of HBV-DNA in different groups

\begin{tabular}{lllll}
\hline Groups & N & \multicolumn{2}{l}{ HBV-DNA } & \\
\cline { 4 - 5 } & & 25 th & 50 th & 75 th \\
\hline Positive IAb (cutoff= 50) & 88 & $<500$ & 521 & 7207 \\
Positive IAg (cutoff= 250) & 21 & 538,000 & $3.2 \times 10^{7}$ & $5.0 \times 10^{7}$ \\
Both IAb and IAg negative & 21 & $<500$ & $<500$ & 3030 \\
Both IAb and IAg positive & 2 & - & - & - \\
\hline
\end{tabular}

Figure 3 shows relationship between $\mathrm{IAb}$ and HBV-DNA in 128 patients. HBV-DNA (lgDNA) was decreased with that IAb value increased. When the values of IAb were greater than 300, the values of HBV-DNA were mostly negative.

\section{Discussion}

Tests for HBV markers (e.g. anti-HBs, anti-HBe and anti-HBc antibodies) now provide quantitative data, so a mathematical model can be established and the information used to fully evaluate the degree of immune response to HBV. Our model (IAb and IAg), established using three quantitative antibody and two antigen tests, may be a way of analyzing and studying different outcomes of $\mathrm{HBV}$ infection. Our results showed that when IAb values were more than 50 , IAg values were mostly less than 250; when IAg values were over 250, IAb values were mostly less than 50 . These results indicated that increased immune response to $\mathrm{HBV}$ can inhibit virus proliferation, and that the mathematical model and the cutoff values were valid in efficiently reflecting viral infection.
Although accurate quantification of HBV can be conducted in infected patients using molecular biological methods, IAg and IAb are important indexes of the extent of in vivo viral proliferation; these two tests (for HBV DNA or serum biomarkers) are related but different [14-16]. HBV infection causes immunologicallymediated damage [17-20], therefore IAg and IAb are directly related to $\mathrm{HBV}$ pathogenesis. No significant difference in IAb was observed between the HBV-DNApositive and -negative groups, suggesting an important role of the immune response to $\mathrm{HBV}$ in pathogenicity and recovery from $\mathrm{HBV}$ infection.

Our results also showed that IAg were mostly negative with IAb values $>50$ and the values of HBV-DNA were mostly negative when the values of IAb increase $>300$, implying that risk of infectivity to other people decreased with the increase of IAb. Therefore, the new laboratory parameters IAb and IAg may be suitable tools to assess infection state during the natural course of $\mathrm{HBV}$ infection and further use of these data in the prediction of HBV infection outcome. We suggest that both IAb and IAg negative status (IAb < 50, IAg < 250) implies an early stage in an infection; IAg-positive (IAg > 250) implies a higher proliferation of the virus; IAb-positive (IAb > 50) implies a stage in loss of tolerance to infection and immune response to $\mathrm{HBV}$; IAb > 300 implies a stage of recovery from an infection; both IAb and IAg positive are rare.

One limitation of this study is that more sensitive test was not used to better categorize HBV-DNA negative/ positive patients. Howerver, the main purpose of this study was to establish a new index for assessment of the

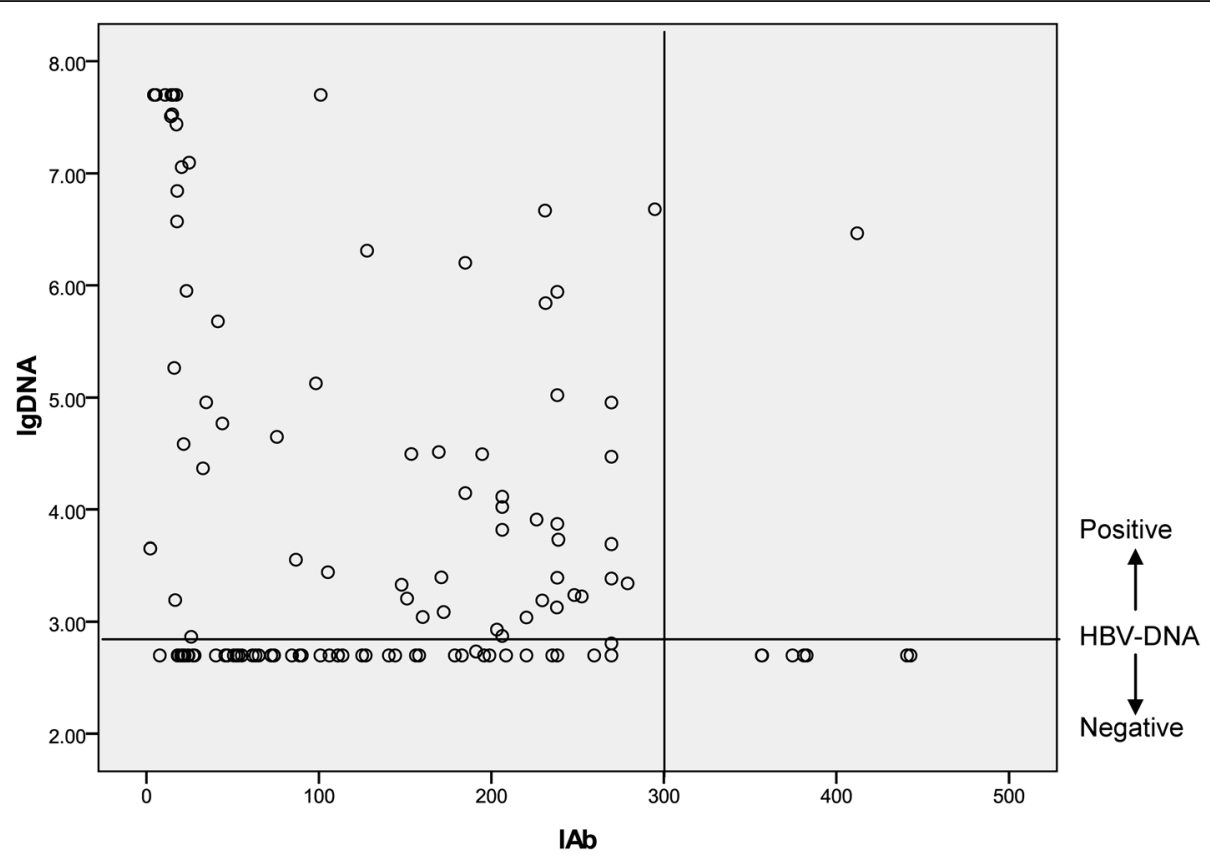

Fig. 3 Relationship between HBV-DNA (data were logarithmically transformed) and IAb in 128 patients 
HBV infection process; our HBV-DNA result from a real-time fluorescence quantitative PCR system could be accepted for this purpose. In the future, relationship of $\mathrm{IAb}$ and IAg should be observed with more parameters, such as the elevation of liver enzymes and HBV-DNA with using higher sensitive system.

\section{Conclusion}

$\mathrm{IAb}$ and IAg values can reflect efficiently immune response status to HBV and may be suitable for assessment of the infection process and the possible outcome of the HBV infection. The detailed clinical significance of IAb and IAg should now be determined by performing studies on various relevant areas of interest related to this disease.

\section{Abbreviations}

anti-HBc: Antibody to hepatitis B core antigen; anti-HBe: Antibody to hepatitis B e antigen; anti-HBs: Antibody to hepatitis B surface antigen; HBeAg: Hepatitis B e antigen; HBsAg: Hepatitis B surface antigen; HBV: Hepatitis B virus; IAb: Antibody index; IAg: Antigen index

\section{Acknowledgements}

We thank Dong Feng for help with data acquisition.

\section{Funding}

None.

\section{Availability of data and materials}

The datasets used and/or analysed during the current study are available from the corresponding author on reasonable request.

\section{Authors' contributions}

LH developed the original idea and the protocol, abstracted and analyzed data, wrote the manuscript, and is guarantor. YG and LY contributed to the development of the protocol, abstracted data, and prepared the manuscript. All the authors read and approved the final manuscript.

\section{Ethics approval and consent to participate}

The Dalian Medical University Ethics Committee approved the study without informed consent, as the samples were remnants following clinical use and therefore not specifically collected for this study and without risk to patients.

\section{Consent for publication}

Not applicable.

\section{Competing interests}

The authors declare that they have no competing interests. rates in the Chinese population over the last 33 years. Vaccine. 2012; 30:3483-7.

4. Bertoletti A, Ferrari C. Adaptive immunity in HBV infection. J Hepatol. 2016; 64(1 Suppl):S71-83.

5. Maini MK, Gehring AJ. The role of innate immunity in the immunopathology and treatment of HBV infection. J Hepatol. 2016;64(1 Suppl):S60-70.

6. Liu H, Han Y, Wang B. A simple method to measure antibody affinity against the hepatitis B surface antigen using a routine quantitative system. J Virol Methods. 2011;173:271-4.

7. Lin C, Kao JH. New perspectives of biomarkers for the management of chronic hepatitis B. Clin Mol Hepatol. 2016;22(4):423-31.

8. Makvandi M. Update on occult hepatitis B virus infection. World J Gastroenterol. 2016;22(39):8720-34.

9. Xiang $Y$, Chen $P$, Xia JR, Zhang LP. A large-scale analysis study on the clinical and viral characteristics of hepatitis B infection with concurrence of hepatitis B surface or E antigens and their corresponding antibodies. Genet Mol Res. 2017;16:1.

10. Ningyu $Z$, Ying $Z$, Hui L. Establishment of a simple model for hepatitis $B$ virus infection status based on trait marker from quantitative measurement of serum markers. J Med Virol. 2015;87:1008-12.

11. Liu H, Han Y, Wang B. Establishment of a new method for the detection of the affinity of antibody to hepatitis $B$ e antigen by a routine quantitative system. Clin Chim Acta. 2011;412(11-12):1022-5.

12. Han $Y$, Wang B, Liu $H$. The novel use of a routine quantitative system to analyze the activity, content and affinity of an antibody to hepatitis B core antigen. J Clin Virol. 2011;52(4):295-9.

13. Kramvis A, Kostaki EG, Hatzakis A, Paraskevis D. Immunomodulatory function of $\mathrm{HBeAg}$ related to short-sighted evolution, transmissibility, and clinical manifestation of hepatitis B virus. Front Microbiol. 2018:9:2521.

14. Du X, Liu Y, Ma L, Lu J, Jin Y, Ren S, He Z, Chen X. Virological and serological features of acute hepatitis $B$ in adults. Medicine (Baltimore). 2017;96(7):e6088.

15. Chu CM, Shyu WC, Liaw YF. Immunopathology on hepatocyte expression of HBV surface, core, and $x$ antigens in chronic hepatitis B: clinical and virological correlation. Dig Dis Sci. 2010;55(2):446-51.

16. Thompson AJ, Nguyen T, Iser D, Ayres A, Jackson K, Littlejohn M, Slavin J, Bowden S, Gane EJ, Abbott W, Lau GK, Lewin SR, Visvanathan K, Desmond PV, Locarnini SA. Serum hepatitis B surface antigen and hepatitis B e antigen titers: disease phase influences correlation with viral load and intrahepatic hepatitis B virus markers. Hepatology. 2010;51(6):1933-44.

17. Das A, Maini MK. Innate and adaptive immune responses in hepatitis $B$ virus infection. Dig Dis. 2010;28(1):126-32.

18. Dunn C, Peppa D, Khanna P, Nebbia G, Jones M, Brendish N, Lascar RM, Brown D, Gilson RJ, Tedder RJ, Dusheiko GM, Jacobs M, Klenerman P, Maini MK. Temporal analysis of early immune responses in patients with acute hepatitis B virus infection. Gastroenterology. 2009;137(4):1289-300.

19. Shang C, Wang Z, Liu H. A terminal antibody method based on multiple factors that influence ELISA results for measurement of antibody affinity in clinical specimens. J Virol Methods. 2017;240:42-8.

20. Zhang JY, Zhang Z, Lin F, Zou ZS, Xu RN, Jin L, Fu JL, Shi F, Shi M, Wang HF, Wang FS. Interleukin-17-producing CD4(+) T cells increase with severity of liver damage in patients with chronic hepatitis B. Hepatology. 2010;51(1):81-91.

\section{Publisher's Note}

Springer Nature remains neutral with regard to jurisdictional claims in published maps and institutional affiliations.

Received: 2 May 2018 Accepted: 13 February 2019

Published online: 18 February 2019

\section{References}

1. Twagirumugabe T, Swaibu G, Walker TD, Lindh M, Gahutu JB, Bergström T, Norder $\mathrm{H}$. Hepatitis B virus strains from Rwandan blood donors are genetically similar and form one clade within subgenotype A1. BMC Infect Dis. 2017;17(1):32.

2. Hongfei W, Yunyan Z, Fei Y, Hui L. Evaluation of an artificial neural network to ascertain why there is a high incidence of hepatitis $B$ in the Chinese population after vaccination. Comput Biol Med. 2013;43:1167-70.

3. Liu $H$, Ma $Y$, Wang $H$, Liu Q. Quantitative evaluation of the effect of the hepatitis B vaccine based on the HBsAg- and anti-HBs-positive

Ready to submit your research? Choose BMC and benefit from:

- fast, convenient online submission

- thorough peer review by experienced researchers in your field

- rapid publication on acceptance

- support for research data, including large and complex data types

- gold Open Access which fosters wider collaboration and increased citations

- maximum visibility for your research: over $100 \mathrm{M}$ website views per year

At BMC, research is always in progress.

Learn more biomedcentral.com/submissions 